\title{
Systematic Review \\ Potential Anti-Inflammatory Effect of Rosmarinus officinalis in Preclinical In Vivo Models of Inflammation
}

\author{
Catarina Gonçalves, Daniela Fernandes, Inês Silva (D) and Vanessa Mateus *(D)
}

check for

Citation: Gonçalves, C.; Fernandes, D.; Silva, I.; Mateus, V. Potential Anti-Inflammatory Effect of Rosmarinus officinalis in Preclinical In Vivo Models of Inflammation. Molecules 2022, 27, 609. https:// doi.org/10.3390/molecules27030609

Academic Editors: Takashi Watanabe Visweswara Rao Pasupuleti, Mikako Fujita, Yukio Nagano and Raju Aedla

Received: 26 December 2021

Accepted: 17 January 2022

Published: 18 January 2022

Publisher's Note: MDPI stays neutral with regard to jurisdictional claims in published maps and institutional affiliations.

Copyright: (C) 2022 by the authors. Licensee MDPI, Basel, Switzerland. This article is an open access article distributed under the terms and conditions of the Creative Commons Attribution (CC BY) license (https:// creativecommons.org/licenses/by/ $4.0 /)$.
H\&TRC-Health and Technology Research Center, ESTeSL_Lisbon School of Health Technology, Instituto Politécnico de Lisboa, 1990-096 Lisbon, Portugal; catarinagraisgoncalves@hotmail.com (C.G.); daniela.dsff@gmail.com (D.F.); ines.silva@estesl.ipl.pt (I.S.)

* Correspondence: vanessa.mateus@estesl.ipl.pt; Tel.: +351-218-980-400

\begin{abstract}
This systematic review aimed to evaluate the potential anti-inflammatory effect of Rosmarinus officinalis in preclinical in vivo models of inflammation. A search was conducted in the databases PubMed, Scopus, and Web of Science, with related keywords. The inclusion criteria were inflammation, plant, and studies on rats or mice; while, the exclusion criteria were reviews, studies with in vitro models, and associated plants. The predominant animal models were paw edema, acute liver injury, and asthma. Rosemary was more commonly used in its entirety than in compounds, and the prevalent methods of extraction were maceration and hydrodistillation. The most common routes of administration reported were gavage, intraperitoneal, and oral, on a route-dependent dosage. Treatment took place daily, or was single-dose, on average for 21 days, and it more often started before the induction. The most evaluated biomarkers were tumor necrosis factor (TNF)- $\alpha$, interleukin (IL)-1 $\beta$, IL-6, IL-10, myeloperoxidase (MPO), catalase (CAT), glutathione (GSH), glutathione peroxidase (GPx), malondialdehyde (MDA), and superoxide dismutase (SOD). The best results emerged at a dose of $60 \mathrm{mg} / \mathrm{kg}$, via IP of carnosic acid, a dose of $400 \mathrm{mg} / \mathrm{kg}$ via gavage of Rosmarinus officinalis, and a dose of $10 \mathrm{mg} / \mathrm{kg}$ via IP of rosmarinic acid. Rosmarinus officinalis L. showed anti-inflammatory activity before and after induction of treatments.
\end{abstract}

Keywords: inflammation; Rosmarinus officinalis L.; rosmarinus; rosmarinic acid; carnosic acid; carnosol; rats; mice; mouse

\section{Introduction}

Globally, therapeutic plants have been used by various communities, having a relevant role in the treatment of human and animal diseases. Today, they have been investigated increasingly often because of their benefits and fewer side effects when compared to pharmacological drugs. They can also be used as a complementary treatment to boost therapeutic progress [1].

Rosmarinus officinalis L., which belongs to the Lamiaceae family, is an aromatic evergreen plant with upright stems, whitish-blue flowers, and dark green leaves. It is commonly known as rosemary and is native in countries of the Mediterranean region. Fresh and dried leaves represent the most relevant part of the plant and can be used as a spice or to make herbal tea [2-4].

Rosemary's chemical composition varies in different extracts, but its analysis shows that phenolic diterpenes, triterpenes, and phenolic acids are the most relevant active constituents. Regarding phenolic compounds, carnosic acid, carnosol, and rosmarinic acid, have been declared to have the main therapeutic effects, such as antioxidant, antiinflammatory, antiviral, and antibacterial activities [2-4]. Plant extracts can be obtained from roots, stems, leaves, flowers, fruits, seeds, and bark, using selective solvents and standard procedures. Qualitative and quantitative studies on bioactive compounds isolated from plants depend on the proper selection of extraction method, which is a vital choice for obtaining satisfactory results $[1,4]$. 
The aerial parts of Rosmarinus officinalis have been widely used in different cultures as a food preservative and also as a flavoring agent in foods, beverages, and in cosmetics [2]. They are reported to have a variety of specific therapeutic properties, such as being hypoglycemic, antiatherogenic, antihypertensive, hypocholesterolemic, antioxidant, anti-inflammatory, hepatoprotective, antidepressant, antiproliferative, and antibacterial. It may also improve asthma, cataract, renal colic, peptic ulcer, and physical and mental fatigue [2-4].

Inflammatory diseases are widely known to be the main cause of morbidity across the global population. If inflammation is not controlled, it may result in numerous diseases, including rheumatoid arthritis, multiple sclerosis, inflammatory bowel disease, psoriasis, immune-inflammatory illnesses, and neoplastic transformations. Moreover, chronic inflammation is also associated with stages of tumorigenesis, presenting a risk factor for the occurrence of certain types of cancers. Chronic diseases tend to manifest as a sustained low-grade inflammation. In some of those diseases, treatment still represents a challenge, given the lack of safe and effective medications. As a response to the difficulties in finding safe and effective treatment options to control inflammation, many animal models have been developed to study and evaluate drug anti-inflammatory activities. To carry out these studies, the choice of the appropriate animal model for the preclinical experiment represents a challenge; in order to, afterward, establish the efficacy and translation of the drugs therapeutic properties in humans. Even though there are numerous in vivo models of inflammation, developed to access the potential of anti-inflammatory drugs, the proper selection of an animal model is always crucial. Unsuitable selection of animal models may lead to a false positive or false negative result and, therefore, prevent the identification of a possibly promising drug [5].

This study aimed to evaluate the potential anti-inflammatory effects demonstrated by Rosmarinus officinalis in preclinical in vivo models of inflammation, through a systematic review of the literature.

\section{Results and Discussion}

Applying the research expressions to Pubmed, Scopus, and Web of Science resulted in 338 studies, since 1994. Excluding duplicates and those for which it was not possible to access the full text, resulted in 216 studies for analysis. Some full-text articles were excluded because they did not meet the inclusion criteria, namely (1) without the plant Rosmarinus officinalis $(n=68)$; (2) without inflammation $(n=34)$; and (3) studies carried out in non-rodent animals $(n=4)$. Other full-text articles were excluded because they fit the exclusion criteria: (1) reviews, opinion articles, and clinical cases $(n=11)$; (2) exclusive studies with in vitro models $(n=34)$; and (3) studies with the associated plant $(n=2)$, as shown in Figure 1.

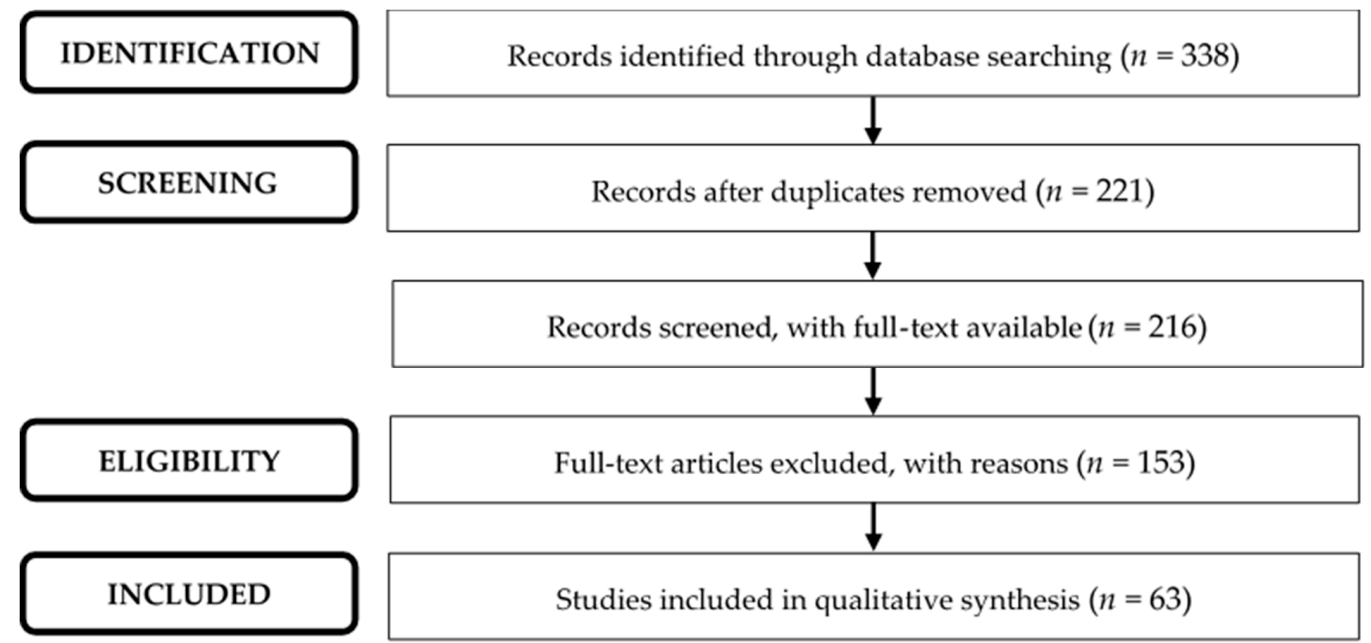

Figure 1. PRISMA flow diagram showing the results of the literature search. 
Data from the selected studies are compiled in Table 1. To gather all crucial data for further analysis, the information was simplified in columns, with parameters of interest for comparison. Therefore, the parameters screened in all reviewed articles were the animal model, the plant or compound studied and how it was extracted, dose and route of administration, frequency and duration of the treatment, and the biomarkers evaluated in the study.

Table 1. Preclinical in vivo models of inflammation using Rosmarinus officinalis as a therapy.

\begin{tabular}{|c|c|c|c|c|c|c|c|}
\hline $\begin{array}{c}\text { Plant/ } \\
\text { Compound }\end{array}$ & Extraction & Dose (mg/kg) & Animal Model & Route & $\begin{array}{l}\text { Frequency/ } \\
\text { Duration }\end{array}$ & $\begin{array}{l}\text { Biomarkers } \\
\text { Evaluated }\end{array}$ & Reference \\
\hline \multirow{12}{*}{ Carnosic acid } & n.m. & 10,20 & $\begin{array}{l}\text { Acute liver } \\
\text { injury }\end{array}$ & Injected & Daily, $5 \mathrm{~d}$ & $\begin{array}{c}\text { TNF- } \alpha, \text { IL- } 1 \beta, \text { IL-6, } \\
\text { IL-18, IFN- } \gamma, \text { TGF- } \beta \text {, } \\
\text { CAT, GPx, GSH, } \\
\text { MDA, SOD }\end{array}$ & [6] \\
\hline & \multirow[t]{2}{*}{ n.a. } & $10-40$ & $\begin{array}{l}\text { Acute lung } \\
\text { injury }\end{array}$ & IP & Single-dose & TNF- $\alpha$, IL-1 $\beta$, IL-6 & [7] \\
\hline & & 15,30 & $\begin{array}{l}\text { Non-alcoholic } \\
\text { fatty liver } \\
\text { disease }\end{array}$ & Oral & Daily, 8 wks & $\begin{array}{c}\text { TNF- } \alpha, \text { IL-1 } \beta, \text { IL-2, } \\
\text { IL-4, IL-6, IL-12, } \\
\text { IL-18, IFN- } \gamma\end{array}$ & [8] \\
\hline & n.m. & 10,20 & Hepatocarcinoma & IP & Daily, 4 wks & $\begin{array}{c}\text { TNF- } \alpha, \text { IL-1 } \beta, \text { IL-2, } \\
\text { IL-6, IL-10, IL-18, } \\
\text { IFN- } \gamma\end{array}$ & [9] \\
\hline & \multirow{8}{*}{ n.a. } & 15,30 & Cirrhosis & \multirow[b]{2}{*}{ Gavage } & Daily, 8 wks & $\mathrm{TNF}-\alpha$ & [10] \\
\hline & & 5 & Cardiotoxicity & & Daily, $6 \mathrm{~d}$ & $\begin{array}{c}\text { TNF- } \alpha, \text { IL-6, COX-2, } \\
\text { CAT, GSH, MDA, } \\
\text { SOD }\end{array}$ & [11] \\
\hline & & 30,60 & Arthritis & \multirow[t]{2}{*}{ IP } & Daily, 4 wks & $\begin{array}{l}\text { TNF- } \alpha, \text { IL-1 } \beta, \text { IL-6, } \\
\text { IL-17, IFN- } \gamma, \\
\text { RANKL, MIP-1, GPx, } \\
\text { MDA, SOD, ROS }\end{array}$ & [12] \\
\hline & & 5 & Arthritis & & $4 \mathrm{wk}, 14 \mathrm{~d}$ & $\begin{array}{c}\text { TNF- } \alpha, \text { IL-1 } \beta, \\
\text { RANKL }\end{array}$ & [13] \\
\hline & & 100,200 & $\begin{array}{l}\text { Diabetes and } \\
\text { hepatic fat } \\
\text { accumulation }\end{array}$ & Oral & Daily, 4 wks & TNF- $\alpha$, IL- 6 & [14] \\
\hline & & 10,20 & Brain injury & \multirow[b]{2}{*}{ Gavage } & Daily, 9 wks & $\begin{array}{c}\text { TNF- } \alpha, \text { IL-1 } \beta, \text { IL-6, } \\
\text { IL-18 }\end{array}$ & [15] \\
\hline & & $15-60$ & $\begin{array}{l}\text { Acute liver } \\
\text { injury }\end{array}$ & & Daily, $35 \mathrm{~d}$ & $\begin{array}{l}\text { TNF- } \alpha, \text { IL-6, GPx, } \\
\text { GSH, MDA, SOD, } \\
\text { NO, iNOS }\end{array}$ & [16] \\
\hline & & n.m. & \multirow{2}{*}{ Ear edema } & \multirow{2}{*}{ Topical } & Single-dose & $\begin{array}{c}\text { TNF- } \alpha, \text { IL- } 1 \beta, \text { COX-1, } \\
\text { COX-2 }\end{array}$ & \multirow{3}{*}{ [17] } \\
\hline \multirow{6}{*}{$\begin{array}{l}\text { Rosmarinus } \\
\text { officinalis }\end{array}$} & \multirow{4}{*}{$\begin{array}{c}\text { Steam } \\
\text { distillation }\end{array}$} & n.m. & & & Single-dose & $\begin{array}{l}\text { Edema, leukocyte } \\
\text { infiltration }\end{array}$ & \\
\hline & & 0.6 & Paw edema & $\begin{array}{l}\text { Topical/ } \\
\text { Injected }\end{array}$ & Single-dose & $\begin{array}{l}\text { Edema, leukocyte } \\
\text { infiltration }\end{array}$ & \\
\hline & & $250-750$ & Paw edema & \multirow{4}{*}{ Gavage } & Single-dose & Edema & \multirow{2}{*}{ [18] } \\
\hline & & $125-500$ & Pleurisy & & Single-dose & $\begin{array}{l}\text { Volume of exudate, } \\
\text { migrated cells }\end{array}$ & \\
\hline & $\begin{array}{l}\text { Aqueous } \\
\text { maceration }\end{array}$ & $100-400$ & $\begin{array}{c}\text { Subcutaneous } \\
\text { edema }\end{array}$ & & Single-dose & $\begin{array}{l}\text { Neutrophil } \\
\text { infiltration, TNF- } \alpha \text {, } \\
\text { IL-6, PGE-2, GPx, } \\
\text { SOD }\end{array}$ & [19] \\
\hline & $\begin{array}{l}\text { Aqueous } \\
\text { maceration }\end{array}$ & 150 & Arthritis & & Daily, $23 \mathrm{~d}$ & $\begin{array}{c}\text { Edema, leukocyte } \\
\text { infiltration, MPO, } \\
\text { CAT, GPx, GSH, } \\
\text { GSSG, GR, SOD, ROS }\end{array}$ & [20] \\
\hline
\end{tabular}


Table 1. Cont.

\begin{tabular}{|c|c|c|c|c|c|c|c|}
\hline $\begin{array}{c}\text { Plant/ } \\
\text { Compound }\end{array}$ & Extraction & Dose (mg/kg) & Animal Model & Route & $\begin{array}{l}\text { Frequency/ } \\
\text { Duration }\end{array}$ & $\begin{array}{l}\text { Biomarkers } \\
\text { Evaluated }\end{array}$ & Reference \\
\hline & \multirow{2}{*}{$\begin{array}{c}\text { Ethanolic Soxhlet } \\
\text { extraction }\end{array}$} & 500,1000 & $\begin{array}{l}\text { Acute intestinal } \\
\text { injury }\end{array}$ & \multirow{2}{*}{ Gavage } & Daily, $3 \mathrm{~d}$ & $\begin{array}{l}\text { MPO, CAT, GSH, } \\
\text { GSSG, MDA, SOD }\end{array}$ & {$[21]$} \\
\hline & & 500,1000 & Gastric ulcer & & Daily, $3 \mathrm{~d}$ & $\begin{array}{c}\text { MPO, CAT, } \\
\text { GSH/GSSG ratio, } \\
\text { MDA, NOx, SOD }\end{array}$ & [22] \\
\hline & \multirow{2}{*}{$\begin{array}{l}\text { Ethanolic } \\
\text { maceration }\end{array}$} & 50 & Ear edema & ID & Single-dose & $\begin{array}{l}\text { Edema, neutrophil } \\
\text { infiltration }\end{array}$ & [23] \\
\hline & & $100-400$ & $\begin{array}{l}\text { Neuropathic } \\
\text { pain }\end{array}$ & $\mathrm{IP}$ & Daily, 14 d & TNF- $\alpha$, Iba-1, iNOS & [24] \\
\hline & & $50-200$ & $\begin{array}{l}\text { Pulmonary } \\
\text { fibrosis }\end{array}$ & \multirow{3}{*}{ Gavage } & Daily, $28 \mathrm{~d}$ & TGF- $\beta$ & [25] \\
\hline & & 100,300 & Paw edema & & Single-dose & Edema & [26] \\
\hline & & 100 & $\begin{array}{l}\text { Inflammation in } \\
\text { hippocampus }\end{array}$ & & Daily, 21 d & $\begin{array}{c}\text { TNF- } \alpha, \text { IL-1 } \beta, \text { Iba-1, } \\
\text { NF- } \kappa B\end{array}$ & [27] \\
\hline & n.d. & 35,70 & Paw edema & IP & Single-dose & Edema & [28] \\
\hline & & $0.46,2.3$ & Asthma & IT & Daily & IL-5, IL-13, MIP-1 & [29] \\
\hline \multirow{12}{*}{$\begin{array}{l}\text { Rosmarinus } \\
\text { officinalis }\end{array}$} & & $1250-5000$ & Paw edema & \multirow{2}{*}{ Oral } & Daily, $15 \mathrm{~d}$ & Edema, MPO & \multirow{2}{*}[30]{} \\
\hline & & $1250-5000$ & Colitis & & Daily, 18 d & IL-1 $\beta$, IL-6, MPO & \\
\hline & & 50,100 & Colitis & Gavage & Daily, $10 \mathrm{~d}$ & $\begin{array}{c}\text { TNF- } \alpha, \text { IL-6, MPO, } \\
\text { NF- } \mathrm{B} \text { B }\end{array}$ & {$[31]$} \\
\hline & n.m & n.m. & $\begin{array}{l}\text { Infected } \\
\text { cutaneous } \\
\text { wounds }\end{array}$ & Topical & Daily, 13 d & IL-3, IL-10 & {$[32]$} \\
\hline & \multirow{6}{*}{ Hydrodistillation } & $125-500$ & $\begin{array}{c}\text { Internal } \\
\text { spermatic fascia } \\
\text { edema }\end{array}$ & Gavage & Single-dose & Leukocyte infiltration & {$[33]$} \\
\hline & & n.m. & Osteoporosis & Oral & n.m. & $\mathrm{TNF}-\alpha, \mathrm{CRP}, \mathrm{MDA}$ & [34] \\
\hline & & 300 & Ear edema & \multirow{6}{*}{ Gavage } & Single-dose & Edema & \multirow{4}{*}{ [35] } \\
\hline & & 300 & Paw edema & & Single-dose & Edema & \\
\hline & & 300 & $\begin{array}{c}\text { Vascular } \\
\text { permeability }\end{array}$ & & Single-dose & Volume of exudate & \\
\hline & & 300 & Granulomatous & & Daily, $6 \mathrm{~d}$ & $\begin{array}{c}\text { Granulomatous } \\
\text { tissue }\end{array}$ & \\
\hline & $\begin{array}{c}\text { Acetone } \\
\text { maceration }\end{array}$ & 2500 & Paw edema & & Single-dose & Edema & [36] \\
\hline & $\begin{array}{l}\text { Ethanolic } \\
\text { maceration }\end{array}$ & 2500 & Paw edema & & Single-dose & Edema & \\
\hline \multirow{4}{*}{$\begin{array}{l}\text { Rosmarinus } \\
\text { officinalis }\end{array}$} & $\begin{array}{l}\text { Hydro-ethanolic } \\
\text { maceration }\end{array}$ & $10-40$ & $\begin{array}{l}\text { Peritoneal } \\
\text { adhesion }\end{array}$ & IP & Single-dose & $\begin{array}{l}\text { TNF- } \alpha, \text { IL- } 1 \beta, \text { IL-6, } \\
\text { TGF- } \beta, \text { GSH, MDA, } \\
\text { NO }\end{array}$ & [37] \\
\hline & $\begin{array}{c}\text { Methanolic } \\
\text { Soxhlet extraction }\end{array}$ & 10,50 & \multirow{2}{*}{ Paw edema } & \multirow[t]{2}{*}{ Gavage } & Single-dose & Edema & \multirow{3}{*}[38]{} \\
\hline & \multirow{2}{*}{ n.a. } & $10-50$ & & & Single-dose & Edema & \\
\hline & & 25 & Thermal injury & IV & Single-dose & TNF- $\alpha$, IL-1 $\beta$, IL-6 & \\
\hline
\end{tabular}


Table 1. Cont.

\begin{tabular}{|c|c|c|c|c|c|c|c|}
\hline $\begin{array}{c}\text { Plant/ } \\
\text { Compound }\end{array}$ & Extraction & Dose (mg/kg) & Animal Model & Route & $\begin{array}{l}\text { Frequency/ } \\
\text { Duration }\end{array}$ & $\begin{array}{l}\text { Biomarkers } \\
\text { Evaluated }\end{array}$ & Reference \\
\hline \multirow{17}{*}{ Rosmarinic acid } & $\begin{array}{l}\text { Chromatography } \\
\text { extraction }\end{array}$ & $10-40$ & Paw edema & Gavage & Single-dose & Edema & [39] \\
\hline & \multirow{4}{*}{ n.a. } & 100 & Sepsis & \multirow{2}{*}{ IP } & Single-dose & $\begin{array}{c}\text { TNF- } \alpha, \text { CAT, GPx, } \\
\text { GSH, SOD }\end{array}$ & {$[40]$} \\
\hline & & $5-20$ & $\begin{array}{l}\text { Acute lung } \\
\text { injury }\end{array}$ & & Single-dose & $\begin{array}{c}\text { TNF- } \alpha, \text { IL-1 } \beta, \text { IL-6, } \\
\text { SOD }\end{array}$ & {$[41]$} \\
\hline & & $5-20$ & Asthma & Oral & Daily, 22 d & $\begin{array}{c}\text { Eosinophils/ } \\
\text { neutrophils/ } \\
\text { monocytes/ } \\
\text { lymphocytes } \\
\text { infiltration, CAT, } \\
\text { MDA, SOD }\end{array}$ & {$[42]$} \\
\hline & & 50 & $\begin{array}{c}\text { Vascular } \\
\text { impairment }\end{array}$ & Gavage & Daily, 10 wks & TNF- $\alpha$, IL-1 $\beta$, IL-6 & [43] \\
\hline & n.m. & $5-20$ & Asthma & Oral & Daily, 22 d & $\begin{array}{l}\text { IL-4, IFN- } \gamma, \text { IgE, } \\
\text { PLA2 }\end{array}$ & {$[44]$} \\
\hline & n.a. & $10-50$ & $\begin{array}{l}\text { Acute liver } \\
\text { injury }\end{array}$ & & Daily, 2 d & $\begin{array}{l}\text { TNF- } \alpha, \text { COX- } 2, \\
\text { TGF- } \beta, \text { SOD }\end{array}$ & [45] \\
\hline & & 200 & Nephrotoxicity & & Daily, $7 \mathrm{~d}$ & TNF- $\alpha$, GSH, MDA & [46] \\
\hline & n.a. & $75-300$ & Hepatocarcinoma & & Daily, $10 \mathrm{~d}$ & $\begin{array}{c}\text { TNF- } \alpha, \text { IL- } 1 \beta, \text { IL-6, } \\
\text { TGF- } \beta\end{array}$ & [47] \\
\hline & n.m. & 40,80 & $\begin{array}{l}\text { Elevation of } \\
\text { C-reactive } \\
\text { protein }\end{array}$ & Gavage & Daily, 8 wks & IL-1 $\beta$, IL-18 & {$[48]$} \\
\hline & n.a. & $75-300$ & Hepatocarcinoma & & Daily, $10 \mathrm{~d}$ & $\begin{array}{l}\text { IL-2, IL-6, IL-10, } \\
\text { IFN- } \gamma\end{array}$ & [49] \\
\hline & & 30,60 & Colitis & & Daily, $7 \mathrm{~d}$ & $\begin{array}{c}\text { IL-1 } \beta, \text { IL-6, IL-22, } \\
\text { COX-2, MPO, iNOS }\end{array}$ & {$[50]$} \\
\hline & n.m. & 10 & $\begin{array}{l}\text { Spinal cord } \\
\text { injury }\end{array}$ & IP & Daily, $7 \mathrm{~d}$ & $\begin{array}{l}\text { TNF- } \alpha, \text { IL-1 } \beta, \text { IL-6, } \\
\text { CAT, GPx, GSH, GST, } \\
\text { MDA, SOD, ROS }\end{array}$ & {$[51]$} \\
\hline & n.a. & 20 & Asthma & & Daily, $3 \mathrm{~d}$ & IL-4, IL-5, IL-13 & [52] \\
\hline & n.a. & $5-20$ & Mastitis & IP & Single-dose & $\begin{array}{c}\text { TNF- } \alpha, \text { IL- } 1 \beta, \text { IL- } 6 \text {, } \\
\text { MPO }\end{array}$ & {$[53]$} \\
\hline & & n.m. & Skin irritation & Topical & $3 d$ & Edema & {$[54]$} \\
\hline & n.m. & 20 & Fat graft & IP & Daily, 8 wks & $\begin{array}{c}\text { TNF- } \alpha, \text { TGF- } \beta 1, \\
\text { MDA }\end{array}$ & {$[55]$} \\
\hline \multirow{6}{*}{ Rosmarinic acid } & n.a. & 10,50 & $\begin{array}{l}\text { Estrogen } \\
\text { deficiency }\end{array}$ & & Daily, 28 d & $\begin{array}{l}\text { IL-18, CAT, GSH, } \\
\text { GSSG, GSH/GSSG } \\
\text { ratio, SOD }\end{array}$ & [56] \\
\hline & & 10 & $\begin{array}{l}\text { Acute liver } \\
\text { injury }\end{array}$ & & Daily, $30 \mathrm{~d}$ & $\begin{array}{l}\text { TNF- } \alpha, \text { IL-6, CAT, } \\
\text { GSH, MDA, SOD }\end{array}$ & {$[57]$} \\
\hline & n.m. & 50 & Nephrotoxicity & Gavage & Daily, $14 \mathrm{~d}$ & $\begin{array}{c}\text { TNF- } \alpha, \text { IL-1 } \beta, \text { IL-6, } \\
\text { CAT, GPx, GR, GSH, } \\
\text { GSSH, GST, NO, } \\
\text { SOD }\end{array}$ & [58] \\
\hline & n.a. & 25,50 & $\begin{array}{l}\text { Neuropathic } \\
\text { pain }\end{array}$ & & Daily, $28 \mathrm{~d}$ & TNF- $\alpha$, IL-6, MDA & [59] \\
\hline & n.m. & 10 & Myringosclerosis & & $5 \mathrm{wk}, 7 \mathrm{~d}$ & Edema & {$[60]$} \\
\hline & n.a. & $10-50$ & \multirow{2}{*}{$\begin{array}{l}\text { Neuropathic } \\
\text { pain }\end{array}$} & & Single-dose & $\begin{array}{c}\text { IL-1 } \beta, \text { COX2, PGE-2, } \\
\text { NO }\end{array}$ & \multirow[b]{2}{*}[61]{} \\
\hline Rosmarinus officinalis & $\begin{array}{l}\text { Ethanolic } \\
\text { Soxhlet } \\
\text { extraction }\end{array}$ & 400 & & IP & Daily, $14 \mathrm{~d}$ & $\begin{array}{c}\text { IL-1 } \beta, \text { COX2, PGE-2, } \\
\mathrm{NO}\end{array}$ & \\
\hline
\end{tabular}


Table 1. Cont.

\begin{tabular}{|c|c|c|c|c|c|c|c|}
\hline $\begin{array}{c}\text { Plant/ } \\
\text { Compound }\end{array}$ & Extraction & Dose (mg/kg) & Animal Model & Route & $\begin{array}{l}\text { Frequency/ } \\
\text { Duration }\end{array}$ & $\begin{array}{l}\text { Biomarkers } \\
\text { Evaluated }\end{array}$ & Reference \\
\hline & $\begin{array}{l}\text { Hydro- } \\
\text { ethanolic } \\
\text { maceration }\end{array}$ & $10-50$ & \multirow[t]{2}{*}{ Paw edema } & & Single-dose & COX-1, COX-2 & \multirow[t]{2}{*}[62]{} \\
\hline \multirow{7}{*}{ Carnosol } & \multirow{3}{*}{ n.a. } & $0.5,1,2$ & & & Single-dose & $\mathrm{COX}-1, \mathrm{COX}-2$ & \\
\hline & & n.m. & Atopic dermatitis & n.m. & Twice & $\begin{array}{c}\text { Edema, TNF- } \alpha \text {, } \\
\text { IL- } 1 \beta, \text { COX-2, iNOS }\end{array}$ & {$[63]$} \\
\hline & & 50 & $\begin{array}{l}\text { Autoimmune en- } \\
\text { cephalomyelitis }\end{array}$ & \multirow{2}{*}{ IP } & Daily & $\begin{array}{c}\text { IL-5, IL-10, IL-17, } \\
\text { FN- } \gamma\end{array}$ & {$[64]$} \\
\hline & n.m. & 5 & $\begin{array}{l}\text { Spinal cord } \\
\text { injury }\end{array}$ & & Daily, $5 \mathrm{~d}$ & $\begin{array}{l}\text { TNF- } \alpha, \text { IL-1 } \beta, \text { IL-6, } \\
\text { CAT, GPx, GSH, GST }\end{array}$ & {$[65]$} \\
\hline & \multirow[b]{2}{*}{ n.a. } & 3 & $\begin{array}{l}\text { Acute kidney } \\
\text { injury }\end{array}$ & IV & Single-dose & TNF- $\alpha$, IL-1 $\beta$, MPO & {$[66]$} \\
\hline & & 0.0125 & Atopic dermatitis & Topical & $3 \mathrm{wk}, 4 \mathrm{wks}$ & $\begin{array}{l}\text { Edema, TNF- } \alpha \text {, } \\
\text { IL-1 } \beta, \text { COX-2, JAK, } \\
\text { iNOS }\end{array}$ & {$[67]$} \\
\hline & $\begin{array}{l}\text { Chromatography } \\
\text { extraction }\end{array}$ & 2.5 & \multirow{3}{*}{ Pleurisy } & \multirow{3}{*}{ IP } & Single-dose & $\begin{array}{c}\text { Leukocyte } \\
\text { infiltration, volume } \\
\text { of exudate, IL-10, } \\
\text { IL-17, MPO, NOx }\end{array}$ & \multirow{3}{*}[68]{} \\
\hline Rosmarinus officinalis & Hydrodistillation & 25,50 & & & Single-dose & $\begin{array}{c}\text { Leukocyte } \\
\text { infiltration, volume } \\
\text { of exudate, IL-10, } \\
\text { IL-17, MPO, NOx }\end{array}$ & \\
\hline Rosmarinic acid & $\begin{array}{l}\text { Chromatography } \\
\text { extraction }\end{array}$ & 5 & & & Single-dose & $\begin{array}{c}\text { Leukocyte } \\
\text { infiltration, volume } \\
\text { of exudate, IL-10, } \\
\text { IL-17, MPO, NOx }\end{array}$ & \\
\hline
\end{tabular}

Legend: d-days; ID_-Intradermal; IP_-Intraperitoneal; IT_-Intrathecal; IV—Intravenous; n.a.-Not applicable n.m.-Not mentioned; wks-weeks.

\subsection{Animal Model}

In the analyzed studies, many models were used in rats and mice to test the antiinflammatory activity of Rosmarinus officinalis. However, most models have only been used once, which makes comparison difficult. Even so, it is possible to highlight that paw edema model was the most used $(n=10)$, followed by models of acute liver injury and asthma $(n=4)$, and then, models of colitis, neuropathic pain, arthritis, ear edema, and hepatocarcinoma $(n=3)$. Some of these models are concordant with findings in the literature, namely, the models of paw edema [69-74], ear edema [71,75-79], and arthritis $[69,74,80]$.

According to the model, the induction method differs. In this review, the method most used for paw edema was injection of carrageenan $(n=6)$; in the case of asthma, it was with ovalbumin $(n=3)$; and in colitis, it was mostly dextran sulfate sodium $(n=2)$. In acute liver injury, no method prevailed.

In the examined studies, the induction of inflammation predominant in paw edema models was an injection of carrageenan. These results are concordant with the literature because the paw edema model was not only the most used, but the preferred pathway of induction was also carrageenan $[69,70,72,73,75,80]$. The literature also showed the use of other pathways such as histamine $[70,74,80]$, dextran $[69,72,74]$, and serotonin $[70,73,80]$. In this review, besides carrageenan, all the other pathways of induction were only used once; therefore, making it unwise to compare.

The paw edema model is prevalent for assessing inflammation, probably because of its high reproducibility, and as it can be used as a preliminary test to screen potential antiinflammatory drugs [5]. Models induced by carrageenan were widely investigated and used because of this substance's ability to cause non-immune acute inflammation [5,81]. These 
models are essential for the development of drugs, and as a response to the inflammation induced by carrageenan the paw increases in size [81].

Although the ear edema model was one of the most investigated, in the analyzed studies and in the literature, all ear edema studies in this review used different induction pathways, which makes comparison difficult. In the literature, the most used methods of induction were oxazolone [71,76,77], 12-O-tetradecanoilforbol acetate (TPA) [78,79,82], ethyl phenylpropionate [75,83], and arachidonic acid [71,78]. However, in one study, inflammation was induced by croton oil, which is the irritant principle of TPA [5]. Ear edema models are valuable for topically assessing the anti-inflammatory and antioxidant potential of plant extracts. In addition, they also assess for steroidal and non-steroidal anti-inflammatory drug activity. TPA-induction inflammation increases cell proliferation and arachidonic acid metabolism in epidermal cells and generates a thickening of the skin $4 \mathrm{~h}$ after induction.

\subsection{Plant/Compound and Extraction}

Regarding the plant, Rosmarinus officinalis, it can be used in its entirety or in the form some of its isolated compounds. In the studies considered in this review, the plant was mostly used in its entirety $(n=31)$. However, rosmarinic acid, one of its compounds, was also extensively used $(n=26)$. Other compounds, such as carnosic acid $(n=12)$ and carnosol $(n=7)$ were less tested.

Studies with some of the main compounds present in Rosmarinus officinalis have been increasing in recent decades. Since 1990, 84 studies about carnosic acid, 46 studies about carnosol, and 32 studies about rosmarinic acid have been published [1]. The literature corroborates the compounds approached in the studies in this review. Although, rosmarinic acid is the compound with the least published studies and in this review, it was the most studied compound after the whole plant. This discrepancy might be related to the inclusion criteria of each study and the type of activity evaluated. For example, carnosic acid and carnosol were used in 35 of 49 cancer studies, because they have a high antitumor activity. Rosmarinic acid extracted from Rosmarinus officinalis has been tested at preclinical stages to assess its anti-inflammatory and antinociceptive activity, demonstrating potential effects at these levels [1].

The plant extract was widely investigated in several clinical diseases by researchers. In some cases, specific compounds of the plant were isolated and then tested to evaluate their activity. Phytotherapy consists of plant-derived treatments where the whole plant is used to produce an extract, and its activity results from a synergic effect between the various compounds. The difference from pharmacotherapy is exactly in this synergy, because this consists of benefits from a single active substance of a drug; the same happens to an isolated compound [1].

A limitation of phytotherapeutic drugs is the natural variability of extracts. In a plant extract, the level of compounds varies, and this causes these drugs to lose biochemical consistency. Ultimately, this results in a reduction of the optimization of safety and efficacy. The natural variability can lead to inconsistent results, and this may impair the extract in being accepted as a phytotherapeutic medicine by the scientific community [1].

The reproducibility of a beneficial effect from a plant extract is greatly reduced, given the fact that multiple factors influence an extract's activity. Some factors, such as the harvesting of the plants at different times and locations, and different extraction and quantification methods, are perhaps the reason for that limitation. The compounds isolation, purification, and structural characterization should be more profoundly developed, and for that reason, methods must be improved. Another limitation in the development of drugs from plants is that the isolation of compounds with therapeutic activity is only done in small quantities, and therefore, is not sufficient for the production of a new drug [1].

Plant extracts have been widely investigated in various clinical diseases by researchers. In some cases, specific compounds of the plant are isolated and then tested to evaluate its activity. 
Not all studies reported how extracts or plant compounds were extracted because, in most of these cases, they were purchased or donated $(n=41)$. When it was possible to access this information, many different ways of extraction were mentioned, with maceration being the most prominent $(n=8)$. Afterward, the most widely used extraction methods were hydrodistillation $(n=7)$, followed by Soxhlet extraction and steam distillation $(n=4)$. Regarding maceration, the most used solvents were ethanol $(n=3)$, followed by water $(n=2)$, and both of them mixed $(n=2)$. In the case of Soxhlet extraction, the most used solvent was ethanol $(n=3)$.

In studies that used maceration as the extraction method for Rosmarinus officinalis, mostly dried and ground leaves were used [19,23,24,37,62]. Powder extraction was performed in a mixer with shaking [37], or slowly [62], with distilled water [19], ethanol [23,24], or both $[37,62]$. The extraction time varied according to the study. The temperature used was not mentioned in all studies, but the studies that noted this used room temperature $[19,23,62]$. The extract was filtered, and the solvent was evaporated $[23,24,37,62]$ on a rotary evaporator [24,37].

Rosmarinus officinalis extracts can be obtained from several parts of the plant, such as the roots, leaves, stems, or flowers. The size of the particles influences the extraction. Thus, smaller particles are preferable, because they have more contact with the solution, which improves the extraction. Consequently, particles in the form of powder provide better extracts, because there is a much higher contact between the plant's particles and the solvent [4]. The solvent's temperature and pressure, as well as the extraction time, also affect the efficiency of the extraction process. In the literature, the most used extraction methods to isolate the compounds of Rosmarinus officinalis were maceration, hydrodistillation, distillation, and Soxhlet by supercritical fluid extraction [1]. These data are in agreement with the information contained in the studies of this review. However, contrary to the literature, in these studies, the extraction by Soxhlet was not performed using supercritical fluid extraction.

The solvent used for extraction influences which compounds are extracted, and individual extracts have a different activity depending on their compounds. The extraction method chosen will influence the final compounds in the extract, so the choice of method should take into account the properties of the plant [4].

\subsection{Dose and Route of Administration}

Given the variety of beneficial effects that Rosmarinus officinalis has shown, numerous in vivo animal models were conducted to test a series of doses of this plant. In the analyzed studies, several routes of administration were used, such as gavage, intraperitoneal (IP), oral (included in diet), intravenous, intrathecal, intradermal, and topical. The prevalent routes were gavage $(n=37)$, intraperitoneal $(n=21)$, and oral $(n=7)$. The effects of Rosmarinus officinalis, rosmarinic acid, carnosic acid, and carnosol were evaluated, and the administered doses differed according to the route. In all analyzed studies, for all doses, regardless of route and compound used, the authors had positive results.

\subsubsection{Gavage}

Gavage (esophageal or gastric) is frequently used in research investigations to guarantee a well-defined and accurate dosing of animals, preferably combining substances with food or water. The administration of Rosmarinus officinalis by gavage $(n=18)$ provided an average dose of approximately $435 \mathrm{mg} / \mathrm{kg}$, ranging between 10 and $2500 \mathrm{mg} / \mathrm{kg}$. In one of the studies, by Faria et al. (2011), the effective dose of Rosmarinus officinalis was evaluated and determined to be $300 \mathrm{mg} / \mathrm{kg}$. Furthermore, according to Takaki et al. (2008), $3000 \mathrm{mg} / \mathrm{kg}$ was determined to be the maximum dose that did not show any cases of lethality or signs of toxicity. The rosmarinic acid doses ranged between 10 and $300 \mathrm{mg} / \mathrm{kg}$ and provided an average dose of approximately $70 \mathrm{mg} / \mathrm{kg}$, significantly higher than the other compound's average. The carnosic acid average dose was roughly $25 \mathrm{mg} / \mathrm{kg}$, varying 
within 5 and $60 \mathrm{mg} / \mathrm{kg}$. Comparing these data, we can verify that the doses used of isolated compounds of the plant were significantly lower.

This systematic review revealed that a higher number of studies were conducted to analyze the effects of Rosmarinus officinalis in comparison with those to evaluate an isolated compound of the plant. Even though rosmarinic acid was more common overall, having significantly more studies than carnosic acid and carnosol. Through analyzing the data, it seems that the use of the whole plant corresponds with a necessity of higher doses, compared to studies of a concentrated substance.

Gavage presents some limitations, such as a delayed onset of the effect when compared with parenteral administration, decrease of absorption of substances, and substance degradation by digestive enzymes and acid. Furthermore, a potentially significant first-pass effect by the liver, may reduce the drug's efficacy for the substances metabolized via this route. In this sense, the dosage through oral gavage tends to be higher [84].

\subsubsection{Intraperitoneal}

The intraperitoneal route consists of injecting substances into the peritoneal cavity, and this is a widespread method in laboratory rodents [84]. This route was the only one used to verify the effects of the plant and all the isolated compounds mentioned earlier. The administration of rosmarinic acid $(n=7)$ and Rosmarinus officinalis $(n=6)$ were the most common.

Rosmarinic acid was tested in doses varying between 5 and $100 \mathrm{mg} / \mathrm{kg}$, with an average dose of approximately $20 \mathrm{mg} / \mathrm{kg}$. Rosmarinus officinalis provided an average dose of approximately $95 \mathrm{mg} / \mathrm{kg}$, ranging between 10 and $400 \mathrm{mg} / \mathrm{kg}$. The median lethal dose, LD50, was evaluated in one of the studies, by Faria et al. (2011), and determined to be $1000 \mathrm{mg} / \mathrm{kg}$. Concerning carnosol $(n=4)$, its administration was mainly tested in significantly lower doses, ranging between 0.5 and $2.5 \mathrm{mg} / \mathrm{kg}$ in most studies. One particular study reported the use of $50 \mathrm{mg} / \mathrm{kg}$. Therefore, carnosol presented an average dose of about $10 \mathrm{mg} / \mathrm{kg}$. Last, in the case of carnosic acid $(n=4)$, the administrated doses ranged between lower values, from 5 to $60 \mathrm{mg} / \mathrm{kg}$, giving an average dose of roughly $25 \mathrm{mg} / \mathrm{kg}$.

In this systematic review, the number of studies regarding the evaluation of Rosmarinus officinalis and its main compounds through the intraperitoneal route were comparable to the gavage route. Even so, with this route, the plant and all compounds were assessed, providing a unique opportunity for comparison. Thus, comparing the doses used in each case, the use of lower doses in comparison with the gavage route was found, for both the plant and all isolated compounds. The tendency for higher doses in the usage of the whole plant seems to be transversal. It was also possible to establish that the average doses of rosmarinic acid and carnosic acid were similar, but in carnosol's case, much lower doses were tested.

Intraperitoneal delivery is recognized as a parenteral route of administration. Parenteral administration methods usually provide the largest bioavailability. Those methods tend to evade the first-pass effect, which occurs commonly with oral administration. Therefore, in cases of intraperitoneal administration, the dosage tended to be lower in comparison with oral delivery [84].

\subsubsection{Oral}

The administration of substances directly into the oral cavity, such as inclusion in diet (food or water), is well-established in laboratory animal experimentation. Oral administration is more economical, convenient, and moderately safe. Doses of the plant or an isolated compound given through the oral route were included in the diet, and the animals had ad libitum access to food. Consequently, this makes it difficult to truly evaluate the real results, because not all animals ingested the same amount of the plant or the compound under analysis. 
Even so, for oral administration of Rosmarinus officinalis $(n=2)$, the average distributed dose was approximately $2900 \mathrm{mg} / \mathrm{kg}$, ranging between 1250 and $5000 \mathrm{mg} / \mathrm{kg}$. Regarding isolated compounds, both carnosic acid $(n=2)$ and rosmarinic acid $(n=2)$ were tested. Carnosic acid was distributed in doses from 5 to $20 \mathrm{mg} / \mathrm{kg}$, with an average of nearly $12 \mathrm{mg} / \mathrm{kg}$. In the case of rosmarinic acid, the average distributed dose was roughly $20 \mathrm{mg} / \mathrm{kg}$, with a broader range between 15 and $200 \mathrm{mg} / \mathrm{kg}$.

As verified for every route of administration, the use of the whole plant, as an extract, always represents a higher dosage than the administration of an isolated compound. Previous reports established the use of higher doses when studies are conducted with extracts, with lower doses of isolated constituents, when studying anti-inflammatory properties [5].

\subsection{Frequency and Duration}

There are numerous factors to take into consideration when establishing the frequency of administration in a treatment. The specific model of inflammation, route, and dose used must be considered in the decision-making process. In the analyzed studies, the doses were mainly administered daily $(n=40)$, followed by treatments as a single-dose $(n=31)$. The use of single-doses versus daily administration depends on the specific therapeutic benefits, the disease or model of inflammation, and the dose under evaluation, to fully access that treatment option.

The duration of treatment depends directly on the animal model, adapting to the conditions under analysis. In the studies in this review, the mean days that a treatment took place was 21 days, with a median of 14 days, and mode of 28 days. Therefore, from all studies reporting the duration of treatment $(n=42)$, there was a balance between treatments under $(n=21)$ and over $(n=21) 14$ days. In the analyzed studies, treatment for 28 days $(n=7)$ was the most common.

In humans, acute inflammation is characterized by an immediate start, increasing the severity in a short time, and symptoms may persist for a few days. Subacute inflammation is the period between acute and chronic inflammation and may last 2 to 6 weeks. Therefore, a persistent inflammation that lasts for more than six weeks is considered chronic. Chronic inflammation is also associated with a slow, long-term inflammation, enduring for prolonged periods of several months to years [85]. Considering the mean life expectancy for humans versus rodents, it seems plausible to infer that in the case of rodents, chronic inflammation would develop faster, and under six weeks. Even so, the authors do not specify a timestamp in which inflammation is considered chronic for the animal. The most accurate information they give is an expectation that, with acute inflammation, it should resolve in days, or maybe a few weeks; while, chronic inflammation extends for weeks, months, or perhaps even years [86].

\subsection{Biomarkers Evaluated}

Regarding the inflammatory mediators mentioned in this review, TNF- $\alpha$, IL-1 $\beta$, IL-6, and myeloperoxidase (MPO), were by far the most evaluated. In all cases, an increase in these inflammatory biomarkers confirmed the onset of the inflammation. As expected, the level of those biomarkers of inflammation suffered a reduction following treatment. Interleukin 10 (IL-10), an anti-inflammatory cytokine, was also evaluated in a variety of studies, and treatment also caused the increase of this cytokine; therefore, contributing to diminishing the inflammation. These effects are evidence of the anti-inflammatory activity of Rosmarinus officinalis, as well as the isolated compounds analyzed. Inflammation and oxidative stress are intertwined in the numerous pathophysiological events of various diseases [5].

Regarding the oxidative stress mediators mentioned in this review, antioxidant enzymes were widely evaluated, given their connection with inflammation. In the analyzed studies, the evaluation of superoxide dismutase (SOD), catalase (CAT), reduced glutathione (GSH), and glutathione peroxidase (GPx) was taken into consideration for their possible 
effect on inflammatory conditions. In all the studies present in this review, a decrease of these biomarkers was verified after the induction of inflammation; consequently, manifesting as an increment in oxidative stress. As expected, the levels of antioxidant biomarkers increased following treatment, potentiating the endogenous antioxidant activity, and therefore, contributing to lessening inflammation. These effects are evidence of the antioxidant activity of Rosmarinus officinalis, as well as its isolated compounds.

The analyzed studies refer to several inflammatory pathways related to the antiinflammatory activity of the plant Rosmarinus officinalis, as well as its main compounds. Consequently, transcription factor NF- $\mathrm{KB}$ was the most commonly stated $(n=17)$, followed by mentions of nitric oxide (NO) $(n=5)$ and cyclooxygenase- 2 (COX-2) $(n=2)$. It has been demonstrated that rosemary extract inhibits NF- $\kappa$ B activation [3]. The authors report that the anti-inflammatory effect of Rosmarinus officinalis can be mediated by inhibition of NF- $\mathrm{B}$ pathways, reducing the expression of COX-2 and inducible nitric oxide synthase (iNOS) $[15,21,28,60]$.

Carnosol and carnosic acid, the main phenolic diterpenoid compounds of rosemary, have been noted to inhibit NO production. The inhibitory effects of carnosic acid in NO and TNF- $\alpha$ production are the result of the suppression of iNOS and COX-2 expression. Moreover, this inhibits the nuclear translocation of NF- $\mathrm{BB}$. Carnosol attenuates the levels of iNOS and also downregulates NF- $\mathrm{B}$ [87]. Moreover, this review's findings support these data $[7,63]$. However, the authors state that the antioxidative and anti-inflammatory activity of either carnosic acid or carnosol alone is weaker than that of rosemary extract [87]. Other authors speculate that rosmarinic acid might exhibit an anti-inflammatory activity by inhibition of neutrophil activity, inhibition of MMP-9 activity, and modulation of the NF- $\kappa$ B pathway [88], accordingly to our findings [47-51].

Regarding inflammatory pathways, the literature reports that the transcription factors NF- $\mathrm{KB}$ and signal transducer and activator of transcription 3 (STAT3); inflammatory enzymes, particularly COX-2 and matrix metalloproteinase-9 (MMP-9); and last, inflammatory cytokines such as TNF- $\alpha$, IL-1, IL-6, and IL-8 are the main molecular mediators of an inflammatory response. Among these mediators, transcription factor NF- $\mathrm{BB}$ is the principal regulator of the immune system and the inflammatory response and controls several genes encoding the cytokines, cytokine receptors, and cell adhesion molecules associated with inflammation triggering $[5,89]$.

\section{Materials and Methods}

\subsection{Search Strategy}

Following the establishment of a review protocol based on a PRISMA methodology, the electronic databases used to search for studies were Pubmed, Scopus, and Web of Science. The keywords adapted to this study were introduced into the MeSH database to confirm if they were MeSH terms.

Depending on the database used, the terminology of the terms varied.

\subsection{Selection of Studies}

The inclusion criteria used in this systematic review included (1) inflammation, (2) presence of the plant Rosmarinus officinalis, and (3) studies carried out on rats or mice. The exclusion criteria used were (1) reviews, opinion articles, and clinical cases; (2) studies with exclusively in vitro models; and (3) studies with Rosmarinus officinalis mixed with other plants.

\subsection{Data Extraction}

The studies selected from Pubmed, Scopus, and Web of Science were analyzed by two reviewers independently. Then, the studies were compared based on various characteristics, such as animal model, plant/compound, plant/compound extraction, dose, route, frequency/duration, and biomarkers evaluated. The information in agreement was main- 
tained, and the uneven information was reviewed by consensus. The data are presented in detail in Table 1.

\section{Conclusions}

Inflammatory diseases represent the majority of debilitating conditions. Their current therapy presents a tremendous challenge given the lack of safe, effective, and straightforward treatments. Notwithstanding that there are very effective drugs to assist in treating acute inflammation, such as steroidal and non-steroidal anti-inflammatory agents, these do not represent a viable option to treat chronic inflammation. Their regular use can be responsible for causing severe adverse reactions, including gastrointestinal, cardiovascular, and renal irregularities. Therefore, there is a great necessity to investigate further into new anti-inflammatory options with selective action and lower toxicity. Plants and their isolated compounds may represent a promising and groundbreaking source of new treatments, given their well-known anti-inflammatory and anti-oxidant activities [5].

This plant represents a potential treatment for physiological disorders, similarly or superior to the usual medications. In this review, it was possible to confirm the antiinflammatory activity of Rosmarinus officinalis in several animal models, both before and after induction of treatment.

According to our review, Rosmarinus officinalis was mostly used in its entirety or as an extract of rosmarinic acid. Rosmarinus officinalis was used at a dose of $400 \mathrm{mg} / \mathrm{kg}$ via gavage and rosmarinic acid at a dose of $10 \mathrm{mg} / \mathrm{kg}$ via IP. Overall, the treatments were scheduled as daily administrations for 28 weeks. Rosmarinus officinalis showed anti-inflammatory activity, before and after induction treatments, with a decrease in the levels of inflammatory biomarkers and an increase of oxidative stress biomarkers.

Although the potent anti-inflammatory properties of rosemary extract have been well recognized in this review, more reliable trials are required in the future. Further evaluation of Rosmarinus officinalis and its main active compounds' safety and efficacy in managing different pathological conditions is crucial.

This review may represent the first step in this revolutionary line of study and towards possible therapies.

Author Contributions: Conceptualization, V.M.; methodology, V.M.; validation, I.S.; formal analysis, C.G. and D.F.; investigation, C.G. and D.F.; data curation, C.G., D.F. and I.S.; writing-original draft preparation, C.G. and D.F.; writing-review and editing, V.M. All authors have read and agreed to the published version of the manuscript.

Funding: This research received no external funding.

Institutional Review Board Statement: Not applicable. Since it is a systemic review manuscript, this study did not involve humans or animals.

Informed Consent Statement: Not applicable.

Acknowledgments: H\&TRC authors gratefully acknowledge the FCT/MCTES national support through the UIDB/05608/2020 and UIDP/05608/2020.

Conflicts of Interest: The authors declare no conflict of interests.

\section{References}

1. Andrade, J.M.; Faustino, C.; Garcia, C.; Ladeiras, D.; Reis, C.P.; Rijo, P. Rosmarinus officinalis L.: An update review of its phytochemistry and biological activity. Future Sci. OA 2018, 4, 1-18. [CrossRef]

2. Farkhondeh, T.; Samarghandian, S.; Pourbagher-Shahri, A.M. Hypolipidemic effects of Rosmarinus officinalis L. J. Cell Physiol. 2019, 234, 14680-14688. [CrossRef]

3. Ahmed, H.M.; Babakir-Mina, M. Investigation of rosemary herbal extracts (Rosmarinus officinalis) and their potential effects on immunity. Phyther. Res. 2020, 34, 1829-1837. [CrossRef]

4. de Oliveira, J.R.; Camargo, S.E.A.; de Oliveira, L.D. Rosmarinus officinalis L. (rosemary) as therapeutic and prophylactic agent. J. Biomed. Sci. 2019, 26, 5. [CrossRef] 
5. Patil, K.R.; Mahajan, U.B.; Unger, B.S.; Goyal, S.N.; Belemkar, S.; Surana, S.J.; Ojha, S.; Patil, C.R. Animal models of inflammation for screening of anti-inflammatory drugs: Implications for the discovery and development of phytopharmaceuticals. Int. J. Mol. Sci. 2019, 20, 4367. [CrossRef]

6. Li, H.; Sun, J.-J.; Chen, G.-Y.; Wang, W.-W.; Xie, Z.-T.; Tang, G.-F.; Wei, S.-D. Carnosic acid nanoparticles suppress liver ischemia/reperfusion injury by inhibition of ROS, Caspases and NF-kB signaling pathway in mice. Biomed. Pharmacother. 2016, 82, 237-246. [CrossRef] [PubMed]

7. Li, Q.; Liu, L.; Sun, H.; Cao, K. Carnosic acid protects against lipopolysaccharide-induced acute lung injury in mice. Exp. Ther. Med. 2019, 18, 3707-3714. [CrossRef]

8. $\quad$ Song, H.-M.; Li, X.; Liu, Y.-Y.; Lu, W.-P.; Cui, Z.-H.; Zhou, L.; Yao, D.; Zhang, H.-M. Carnosic acid protects mice from high-fat diet-induced NAFLD by regulating MARCKS. Int. J. Mol. Med. 2018, 42, 193-207. [CrossRef]

9. Tang, B.; Tang, F.; Wang, Z.; Qi, G.; Liang, X.; Li, B.; Yuan, S.; Liu, J.; Yu, S.; He, S. Upregulation of Akt/Nf-kB-regulated inflammation and Akt/Bad-related apoptosis signaling pathway involved in hepatic carcinoma process: Suppression by carnosic acid nanoparticle. Int. J. Nanomed. 2016, 11, 6401-6420. [CrossRef] [PubMed]

10. Gao, L.; Shan, W.; Zeng, W.; Hu, Y.; Wang, G.; Tian, X.; Zhang, N.; Shi, X.; Zhao, Y.; Ding, C.; et al. Carnosic acid alleviates chronic alcoholic liver injury by regulating the SIRT1/ChREBP and SIRT1/p66shc pathways in rats. Mol. Nutr. Food Res. 2016, 60, 1902-1911. [CrossRef] [PubMed]

11. Zhang, Q.-L.; Yang, J.-J.; Zhang, H.-S. Carvedilol (CAR) combined with carnosic acid (CAA) attenuates doxorubicin-induced cardiotoxicity by suppressing excessive oxidative stress, inflammation, apoptosis and autophagy. Biomed. Pharmacother. 2019, 109, 71-83. [CrossRef]

12. Xia, G.; Wang, X.; Sun, H.; Qin, Y.; Fu, M. Carnosic acid (CA) attenuates collagen-induced arthritis in db/db mice via inflammation suppression by regulating ROS-dependent p38 pathway. Free Radic. Biol. Med. 2017, 108, 418-432. [CrossRef] [PubMed]

13. Liu, M.; Zhou, X.; Zhou, L.; Liu, Z.; Yuan, J.; Cheng, J.; Zhao, J.; Wu, L.; Li, H.; Qiu, H.; et al. Carnosic acid inhibits inflammation response and joint destruction on osteoclasts, fibroblast-like synoviocytes, and collagen-induced arthritis rats. J. Cell Physiol. 2018, 233, 6291-6303. [CrossRef]

14. Park, M.-Y.; Sung, M.-K. Carnosic acid attenuates obesity-induced glucose intolerance and hepatic fat accumulation by modulating genes of lipid metabolism in C57BL/6J-ob/ob mice. J. Sci. Food Agric. 2015, 95, 828-835. [CrossRef]

15. Liu, Y.; Zhang, Y.; Hu, M.; Li, Y.-H.; Cao, X.-H. Carnosic acid alleviates brain injury through NF-kB-regulated inflammation and Caspase-3-associated apoptosis in high fat-induced mouse models. Mol. Med. Rep. 2019, 20, 495-504. [CrossRef]

16. Xiang, Q.; Liu, Z.; Wang, Y.; Xiao, H.; Wu, W.; Xiao, C.; Liu, X. Carnosic acid attenuates lipopolysaccharide-induced liver injury in rats via fortifying cellular antioxidant defense system. Food Chem. Toxicol. 2013, 53, 1-9. [CrossRef]

17. Mengoni, E.S.; Vichera, G.; Rigano, L.A.; Rodriguez-Puebla, M.L.; Galliano, S.R.; Cafferata, E.E.; Pivetta, O.H.; Moreno, S.; Vojnov, A.A. Suppression of COX-2, IL-1 $\beta$ and TNF- $\alpha$ expression and leukocyte infiltration in inflamed skin by bioactive compounds from Rosmarinus officinalis L. Fitoterapia 2011, 82, 414-421. [CrossRef]

18. Takaki, I.; Bersani-Amado, L.E.; Vendruscolo, A.; Sartoretto, S.M.; Diniz, S.P.; Bersani-Amado, C.A.; Cuman, R.K.N. Antiinflammatory and antinociceptive effects of Rosmarinus officinalis L. essential oil in experimental animal models. J. Med. Food 2008, 11,741-746. [CrossRef]

19. de Oliveira E Silva, A.M.; Machado, I.D.; Santin, J.R.; Pereira de Melo, I.L.; Pedrosa, G.V.; Genovese, M.I.; Farsky, S.H.P.; Mancini-Filho, J. Aqueous extract of Rosmarinus officinalis L. inhibits neutrophil influx and cytokine secretion. Phyther. Res. 2015, 29, 125-133. [CrossRef] [PubMed]

20. Goncalves, G.A.; Sa-Nakanishi, A.B.D.; Comar, J.F.; Bracht, L.; Dias, M.I.; Barros, L.; Peralta, R.M.; Ferreira, I.C.F.R.; Bracht, A Water soluble compounds of Rosmarinus officinalis L. improve the oxidative and inflammatory states of rats with adjuvant-induced arthritis. Food Funct. 2018, 9, 2328-2340. [CrossRef] [PubMed]

21. Amaral, G.P.; Dobrachinski, F.; de Carvalho, N.R.; Barcelos, R.P.; da Silva, M.H.; Lugokenski, T.H.; Dias, G.R.M.; Portella, R.L.; Fachinetto, R.; Soares, F.A.A. Multiple mechanistic action of Rosmarinus officinalis L. extract against ethanol effects in an acute model of intestinal damage. Biomed. Pharmacother. 2018, 98, 454-459. [CrossRef] [PubMed]

22. Amaral, G.P.; de Carvalho, N.R.; Barcelos, R.P.; Dobrachinski, F.; Portella, R.L.; da Silva, M.H.; Lugokenski, T.H.; Dias, G.R.M.; da Luz, S.C.A.; Boligon, A.A.; et al. Protective action of ethanolic extract of Rosmarinus officinalis L. in gastric ulcer prevention induced by ethanol in rats. Food Chem. Toxicol. 2013, 55, 48-55. [CrossRef] [PubMed]

23. Tsai, T.-H.; Chuang, L.-T.; Lien, T.-J.; Liing, Y.-R.; Chen, W.-Y.; Tsai, P.-J. Rosmarinus officinalis extract suppresses propionibacterium acnes-induced inflammatory responses. J. Med. Food 2013, 16, 324-333. [CrossRef] [PubMed]

24. Rahbardar, M.G.; Amin, B.; Mehri, S.; Mirnajafi-Zadeh, S.J.; Hosseinzadeh, H. Effect of alcoholic extract of aerial parts of Rosmarinus officinalis L. on pain, inflammation and apoptosis induced by chronic constriction injury (CCI) model of neuropathic pain in rats. J. Ethnopharmacol. 2016, 194, 117-130. [CrossRef]

25. Yang, L.; Liu, X.; Cheng, D.; Fang, X.; Mu, M.; Hu, X.; Nie, L. Inhibition of bleomycin-induced pulmonary fibrosis by extract from Rosmarinus officinalis in rats. Int. J. Clin. Exp. Med. 2016, 9, 6054-6061.

26. Borges, R.S.; Lima, E.S.; Keita, H.; Ferreira, I.M.; Fernandes, C.P.; Cruz, R.A.S.; Duarte, J.L.; Vélázquez-Moyado, J.; Ortiz, B.L.S.; Castro, A.N.; et al. Anti-inflammatory and antialgic actions of a nanoemulsion of Rosmarinus officinalis L. essential oil and a molecular docking study of its major chemical constituents. Inflammopharmacology 2018, 26, 183-195. [CrossRef] 
27. Guo, Y.; Xie, J.; Li, X.; Yuan, Y.; Zhang, L.; Hu, W.; Luo, H.; Yu, H.; Zhang, R. Antidepressant Effects of Rosemary Extracts Associate with Anti-inflammatory Effect and Rebalance of Gut Microbiota. Front. Pharmacol. 2018, 9, 1-13. [CrossRef]

28. Draganova-Filipova, M.; Apostolova, E.; Zagorchev, P. Effects of Rosmarinus officinalis oil on histamine-induced acute inflammation. C. R. Acad. Bulg. Sci. 2018, 71, 261-270.

29. Inoue, K.-I.; Takano, H.; Shiga, A.; Fujita, Y.; Makino, H.; Yanagisawa, R.; Ichinose, T.; Kato, Y.; Yamada, T.; Yoshikawa, T. Effects of volatile constituents of a rosemary extract on allergic airway inflammation related to house dust mite allergen in mice. Int. $J$. Mol. Med. 2005, 16, 315-319. [CrossRef]

30. Juhás, Š.; Bukovská, A.; Čikoš, Š.; Czikková, S.; Fabian, D.; Koppel, J. Anti-inflammatory effects of Rosmarinus officinalis essential oil in mice. Acta Vet. Brno 2009, 78, 121-127. [CrossRef]

31. Medicherla, K.; Ketkar, A.; Sahu, B.D.; Sudhakar, G.; Sistla, R. Rosmarinus officinalis L. extract ameliorates intestinal inflammation through MAPKs/NF-кB signaling in a murine model of acute experimental colitis. Food Funct. 2016, 7, 3233-3243. [CrossRef]

32. Khezri, K.; Farahpour, M.R.; Rad, S.M. Accelerated infected wound healing by topical application of encapsulated Rosemary essential oil into nanostructured lipid carriers. Artif. Cells Nanomed. Biotechnol. 2019, 47, 980-988. [CrossRef]

33. de Melo, G.A.N.; Grespan, R.; Fonseca, J.P.; Farinha, T.O.; Silva, E.L.; Romero, A.L.; Bersani-Amado, C.A.; Cuman, R.K.N. Rosmarinus officinalis L. Essential Oil Inhibits In Vivo and In Vitro Leukocyte Migration. J. Med. Food. 2011, 14, 944-949. [CrossRef]

34. Elbahnasawy, A.S.; Valeeva, E.R.; El-Sayed, E.M.; Rakhimov, I.I. The Impact of Thyme and Rosemary on Prevention of Osteoporosis in Rats. J. Nutr. Metab. 2019, 2019, 1431384. [CrossRef]

35. de Faria, L.R.D.; Lima, C.L.; Perazzo, F.F.; Carvalho, J.C.T. Anti-inflammatory and antinociceptive activities of the essential oil from Rosmarinus Officinalis L. (lamiaceae). Int. J. Pharm. Sci. Rev. Res. 2011, 7, 1-8.

36. Grigore, A.; Pirvu, L.; Bubueanu, C.; Panteli, M.; Rasit, I. Influence of chemical composition on the antioxidant and antiinflammatory activity of Rosmarinus officinalis extracts. Rom. Biotechnol. Lett. 2015, 20, 10047-10054.

37. Roohbakhsh, Y.; Rahimi, V.B.; Silakhori, S.; Rajabi, H.; Rahmanian-Devin, P.; Samzadeh-Kermani, A.; Rakhshandeh, H.; Hasanpour M.; Iranshahi, M.; Mousavi, S.H.; et al. Evaluation of the Effects of Peritoneal Lavage with Rosmarinus officinalis Extract against the Prevention of Postsurgical-Induced Peritoneal Adhesion. Planta Med. 2020, 86, 405-414. [CrossRef] [PubMed]

38. Rocha, J.; Eduardo-Figueira, M.; Barateiro, A.; Fernandes, A.; Brites, D.; Bronze, R.; Duarte, C.M.M.; Serra, A.T.; Pinto, R.; Freitas, M.; et al. Anti-inflammatory effect of rosmarinic acid and an extract of Rosmarinus officinalis in rat models of local and systemic inflammation. Basic Clin. Pharmacol. Toxicol. 2015, 116, 398-413. [CrossRef] [PubMed]

39. Lucarini, R.; Bernardes, W.A.; Ferreira, D.S.; Tozatti, M.G.; Furtado, R.; Bastos, J.K.; Pauletti, P.M.; Januário, A.H.; Silva, M.L.A.; Cunha, W.R. In vivo analgesic and anti-inflammatory activities of Rosmarinus officinalis aqueous extracts, rosmarinic acid and its acetyl ester derivative. Pharm. Biol. 2013, 51, 1087-1090. [CrossRef]

40. Bacanlı, M.; Aydın, S.; Taner, G.; Göktaş, H.G.; Şahin, T.; Başaran, A.A.; Başaran, N. Does rosmarinic acid treatment have protective role against sepsis-induced oxidative damage in Wistar Albino rats? Hum. Exp. Toxicol. 2015, 35, 877-886. [CrossRef]

41. Chu, X.; Ci, X.; He, J.; Jiang, L.; Wei, M.; Cao, Q.; Guan, M.; Xie, X.; Deng, X.; He, J. Effects of a Natural Prolyl Oligopeptidase Inhibitor, Rosmarinic Acid, on Lipopolysaccharide-Induced Acute Lung Injury in Mice. Molecules 2012, 17, 3586-3598. [CrossRef] [PubMed]

42. Eftekhar, N.; Moghimi, A.; Boskabady, M.H. Prophylactic effect of rosmarinic acid on tracheal responsiveness, white blood cell count and oxidative stress markers in lung lavage of sensitized rats. Pharmacol. Rep. 2018, 70, 119-125. [CrossRef]

43. Sotnikova, R.; Okruhlicova, L.; Vlkovicova, J.; Navarova, J.; Gajdacova, B.; Pivackova, L.; Fialova, S.; Krenek, P. Rosmarinic acid administration attenuates diabetes-induced vascular dysfunction of the rat aorta. J. Pharm. Pharmacol. 2013, 65, 713-723. [CrossRef]

44. Shakeri, F.; Eftekhar, N.; Roshan, N.M.; Rezaee, R.; Moghimi, A.; Boskabady, M.H. Rosmarinic acid affects immunological and inflammatory mediator levels and restores lung pathological features in asthmatic rats. Allergol. Immunopathol. 2019, 47, 16-23. [CrossRef]

45. Domitrović, R.; Škoda, M.; Marchesi, V.V.; Cvijanović, O.; Pugel, E.P.; Štefan, M.B. Rosmarinic acid ameliorates acute liver damage and fibrogenesis in carbon tetrachloride-intoxicated mice. Food Chem. Toxicol. 2013, 51, 370-378. [CrossRef] [PubMed]

46. Hashiesh, H.M.; Elkhoely, A.A.; Eissa, A.A.; Youns, M.M. Rosmarinic acid enhances cisplatin cytotoxicity in hepg2 cell line and attenuates its nephrotoxicity in mice. Int. J. Pharm. Sci. Res. 2018, 9, 2731-2743. [CrossRef]

47. Cao, W.; Hu, C.; Wu, L.; Xu, L.; Jiang, W. Rosmarinic acid inhibits inflammation and angiogenesis of hepatocellular carcinoma by suppression of NF-kB signaling in H22 tumor-bearing mice. J. Pharmacol. Sci. 2016, 132, 131-137. [CrossRef]

48. Yao, Y.; Mao, J.; Xu, S.; Zhao, L.; Long, L.; Chen, L.; Li, D.; Lu, S. Rosmarinic acid inhibits nicotine-induced C-reactive protein generation by inhibiting NLRP3 inflammasome activation in smooth muscle cells. J. Cell Physiol. 2019, 234, 1758-1767. [CrossRef]

49. Cao, W.; Mo, K.; Wei, S.; Lan, X.; Zhang, W.; Jiang, W. Effects of rosmarinic acid on immunoregulatory activity and hepatocellular carcinoma cell apoptosis in H22 tumor-bearing mice. Korean J. Physiol. Pharmacol. 2019, 23, 501-508. [CrossRef]

50. Jin, B.-R.; Chung, K.-S.; Cheon, S.-Y.; Lee, M.; Hwang, S.; Hwang, S.N.; Rhee, K.-J.; An, H.-J. Rosmarinic acid suppresses colonic inflammation in dextran sulphate sodium (DSS)-induced mice via dual inhibition of NF-kB and STAT3 activation. Sci. Rep. 2017, 7, 46252. [CrossRef] [PubMed]

51. Shang, A.-J.; Yang, Y.; Wang, H.-Y.; Tao, B.-Z.; Wang, J.; Wang, Z.-F.; Zhou, D.-B. Spinal cord injury effectively ameliorated by neuroprotective effects of rosmarinic acid. Nutr. Neurosci. 2017, 20, 172-179. [CrossRef] [PubMed] 
52. Liang, Z.; Nie, H.; Xu, Y.; Peng, J.; Zeng, Y.; Wei, Y.; Wen, X.; Qiu, J.; Zhong, W.; Deng, X.; et al. Therapeutic effects of rosmarinic acid on airway responses in a murine model of asthma. Int. Immunopharmacol. 2016, 41, 90-97. [CrossRef]

53. Jiang, K.; Ma, X.; Guo, S.; Zhang, T.; Zhao, G.; Wu, H.; Wang, X.; Deng, G. Anti-inflammatory Effects of Rosmarinic Acid in Lipopolysaccharide-Induced Mastitis in Mice. Inflammation 2018, 41, 437-448. [CrossRef] [PubMed]

54. Budhiraja, A.; Dhingra, G. Development and characterization of a novel antiacne niosomal gel of rosmarinic acid. Drug Deliv. 2015, 22, 723-730. [CrossRef]

55. Cin, B.; Ciloglu, N.S.; Omar, S.; Terzi, N.K. Effect of Rosmarinic Acid and Alcohol on Fat Graft Survival in Rat Model. Aesth. Plast. Surg. 2020, 44, 177-185. [CrossRef]

56. Zych, M.; Kaczmarczyk-Sedlak, I.; Wojnar, W.; Folwarczna, J. Effect of Rosmarinic Acid on the Serum Parameters of Glucose and Lipid Metabolism and Oxidative Stress in Estrogen-Deficient Rats. Nutrients 2019, 11, 267. [CrossRef] [PubMed]

57. Hasanein, P.; Seifi, R. Beneficial effects of rosmarinic acid against alcohol-induced hepatotoxicity in rats. Can. J. Physiol. Pharmacol. 2018, 96, 32-37. [CrossRef]

58. Joardar, S.; Dewanjee, S.; Bhowmick, S.; Dua, T.K.; Das, S.; Saha, A.; de Feo, V. Rosmarinic acid attenuates cadmium-induced nephrotoxicity via inhibition of oxidative stress, apoptosis, inflammation and fibrosis. Int. J. Mol. Sci. 2019, 20, 2027. [CrossRef]

59. Areti, A.; Komirishetty, P.; Kalvala, A.K.; Nellaiappan, K.; Kumar, A. Rosmarinic Acid Mitigates Mitochondrial Dysfunction and Spinal Glial Activation in Oxaliplatin-induced Peripheral Neuropathy. Mol. Neurobiol. 2018, 55, 7463-7475. [CrossRef]

60. Ozdemir, D.; Agri, I.; Bakirtas, M.; Agri, A.; Mehel, D.M.; Celebi, M.; Ozgur, A. The effect of rosmarinic acid on the prevention of myringosclerosis. Int. J. Pediatr. Otorhinolaryngol. 2019, 126, 109597. [CrossRef]

61. Rahbardar, M.G.; Amin, B.; Mehri, S.; Mirnajafi-Zadeh, S.J.; Hosseinzadeh, H. Anti-inflammatory effects of ethanolic extract of Rosmarinus officinalis L. and rosmarinic acid in a rat model of neuropathic pain. Biomed. Pharmacother. 2017, 86, 441-449. [CrossRef]

62. Emami, F.; Ali-Beig, H.; Farahbakhsh, S.; Mojabi, N.; Rastegar-Moghadam, B.; Arbabian, S.; Kazemi, M.; Tekieh, E.; Golmanesh, L.; Ranjbaran, M.; et al. Hydroalcoholic extract of rosemary (Rosmarinus officinalis L.) and its constituent carnosol inhibit formalin-induced pain and Inflammation in mice. Pakistan J. Biol. Sci. 2013, 16, 309-316. [CrossRef]

63. Lee, D.Y.; Hwang, C.J.; Choi, J.Y.; Park, M.H.; Song, M.J.; Oh, K.W.; Son, D.J.; Lee, S.H.; Han, S.B.; Hong, J.T. Inhibitory Effect of Carnosol on Phthalic Anhydride-Induced Atopic Dermatitis via Inhibition of STAT3. Biomol. Ther. 2017, 25, 535-544. [CrossRef]

64. Li, X.; Zhao, L.; Han, J.-J.; Zhang, F.; Liu, S.; Zhu, L.; Wang, Z.-Z.; Zhang, G.-X.; Zhang, Y. Carnosol modulates Th17 cell differentiation and microglial switch in experimental autoimmune encephalomyelitis. Front. Immunol. 2018, 9. [CrossRef] [PubMed]

65. Wang, Z.-H.; Xie, Y.-X.; Zhang, J.-W.; Qiu, X.-H.; Cheng, A.-B.; Tian, L.; Ma, B.-Y.; Hou, Y.-B. Carnosol protects against spinal cord injury through Nrf-2 upregulation. J. Recept. Signal Transduct. 2016, 36, 72-78. [CrossRef] [PubMed]

66. Zheng, Y.; Zhang, Y.; Zheng, Y.; Zhang, N. Carnosol protects against renal ischemia-reperfusion injury in rats. Exp. Anim. 2018, 67, 545-553. [CrossRef] [PubMed]

67. Yeo, I.J.; Park, J.H.; Jang, J.S.; Lee, D.Y.; Park, J.E.; Choi, Y.E.; Joo, J.H.; Song, J.K.; Jeon, H.O.; Hong, J.T. Inhibitory effect of Carnosol on UVB-induced inflammation via inhibition of STAT3. Arch. Pharm. Res. 2019, 42, 274-283. [CrossRef] [PubMed]

68. da Rosa, J.S.; Facchin, B.M.; Bastos, J.; Siqueira, M.A.; Micke, G.A.; Dalmarco, E.M.; Pizzolatti, M.G.; Frode, T.S. Systemic administration of Rosmarinus officinalis attenuates the inflammatory response induced by carrageenan in the mouse model of pleurisy. Planta Med. 2013, 79, 1605-1614. [CrossRef] [PubMed]

69. Babu, N.P.; Pandikumar, P.; Ignacimuthu, S. Anti-inflammatory activity of Albizia lebbeck Benth, an ethnomedicinal plant, in acute and chronic animal models of inflammation. J. Ethnopharmacol. 2009, 125, 356-360. [CrossRef] [PubMed]

70. Nakamura, H.; Shimizu, M. Early and delayed phases of hind paw edema in rats. Jpn. J. Pharmacol. 1974, 24, 393-405. [CrossRef]

71. Moreno, J.J. Effect of aristolochic acid on arachidonic acid cascade and in vivo models of inflammation. Immunopharmacology 1993, 26, 1-9. [CrossRef]

72. Gupta, M.; Mazumder, U.K.; Kumar, R.S.; Gomathi, P.; Rajeshwar, Y.; Kakoti, B.B.; Selven, V.T. Anti-inflammatory, analgesic and antipyretic effects of methanol extract from Bauhinia racemosa stem bark in animal models. J. Ethnopharmacol. 2005, 98, 267-273. [CrossRef] [PubMed]

73. Boominathan, R.; Parimaladevi, B.; Mandal, S.C.; Ghoshal, S.K. Anti-inflammatory evaluation of Ionidium suffruticosam Ging. in rats. J. Ethnopharmacol. 2004, 91, 367-370. [CrossRef] [PubMed]

74. Singh, B.; Bani, S.; Gupta, D.K.; Chandan, B.K.; Kaul, A. Anti-inflammatory activity of "TAF" an active fraction from the plant Barleria prionitis Linn. J. Ethnopharmacol. 2003, 85, 187-193. [CrossRef]

75. Panthong, A.; Norkaew, P.; Kanjanapothi, D.; Taesotikul, T.; Anantachoke, N.; Reutrakul, V. Anti-inflammatory, analgesic and antipyretic activities of the extract of gamboge from Garcinia hanburyi Hook f. J. Ethnopharmacol. 2007, 111, 335-340. [CrossRef] [PubMed]

76. Bas, E.; Recio, M.C.; Máñez, S.; Giner, R.M.; Escandell, J.M.; López-Ginés, C.; Rios, J.-L. New insight into the inhibition of the inflammatory response to experimental delayed-type hypersensitivity reactions in mice by scropolioside A. Eur. J. Pharmacol. 2007, 555, 199-210. [CrossRef]

77. Bas, E.; Recio, M.C.; Abdallah, M.; Máñez, S.; Giner, R.M.; Cerdá-Nicolás, M.; Rios, J.-L. Inhibition of the pro-inflammatory mediators' production and anti-inflammatory effect of the iridoid scrovalentinoside. J. Ethnopharmacol. 2007, 110, 419-427. [CrossRef] 
78. Boller, S.; Soldi, C.; Marques, M.C.A.; Santos, E.P.; Cabrini, D.A.; Pizzolatti, M.G.; Zampronio, A.R.; Otuki, M.F. Anti-inflammatory effect of crude extract and isolated compounds from Baccharis illinita DC in acute skin inflammation. J. Ethnopharmacol. 2010, 130, 262-266. [CrossRef]

79. Inoue, H.; Mori, T.; Shibata, S.; Koshihara, Y. Modulation by glycyrrhetinic acid derivatives of TPA-induced mouse ear oedema. Br. J. Pharmacol. 1989, 96, 204-210. [CrossRef]

80. Vasudevan, M.; Gunnam, K.K.; Parle, M. Antinociceptive and anti-inflammatory effects of Thespesia populnea bark extract. J. Ethnopharmacol. 2007, 109, 264-270. [CrossRef]

81. Morris, C.J. Carrageenan-induced paw edema in the rat and mouse. In Methods in Molecular Biology; Springer: Berlin/Heidelberg, Germany, 2003; pp. 115-121.

82. Sadeghi, H.; Parishani, M.; Touri, M.A.; Ghavamzadeh, M.; Barmak, M.J.; Zarezade, V.; Delaviz, H.; Sadeghi, H. Pramipexole reduces inflammation in the experimental animal models of inflammation. Immunopharmacol. Immunotoxicol. 2017, 39, 80-86. [CrossRef] [PubMed]

83. Panthong, A.; Kanjanapothi, D.; Taesotikul, T.; Wongcome, T.; Reutrakul, V. Anti-inflammatory and antipyretic properties of Clerodendrum petasites S. Moore. J. Ethnopharmacol. 2003, 85, 151-156. [CrossRef]

84. Turner, P.V.; Brabb, T.; Pekow, C.; Vasbinder, M.A. Administration of substances to laboratory animals: Routes of administration and factors to consider. J. Am. Assoc. Lab Anim. Sci. 2011, 50, 600-613. [PubMed]

85. Pahwa, R.; Goyal, A.; Bansal, P.; Jialal, I. Chronic Inflammation. In StatPearls; StatPearls Publishing: Treasure Island, FL, USA, 2018.

86. Cash, J.L.; White, G.E.; Greaves, D.R. Chapter 17-Zymosan-Induced Peritonitis as a Simple Experimental System for the Study of Inflammation. Methods Enzymol. 2009, 461, 379-396. [CrossRef]

87. Yu, M.-H.; Choi, J.-H.; Chae, I.-G.; Im, H.-G.; Yang, S.-A.; More, K.; See, I.-S.; Lee, J. Suppression of LPS-induced inflammatory activities by Rosmarinus officinalis L. Food Chem. 2013, 136, 1047-1054. [CrossRef] [PubMed]

88. Luo, C.; Zou, L.; Sun, H.; Peng, J.; Gao, C.; Bao, L.; Ji, R.; Jin, Y.; Sun, S. A Review of the Anti-Inflammatory Effects of Rosmarinic Acid on Inflammatory Diseases. Front. Pharmacol. 2020, 11, 153. [CrossRef] [PubMed]

89. Kunnumakkara, A.B.; Sailo, B.L.; Banik, K.; Harsha, C.; Prasad, S.; Gupta, S.C.; Bharti, A.C.; Aggarwal, B.B. Chronic diseases, inflammation, and spices: How are they linked? J. Transl. Med. 2018, 16, 14. [CrossRef] 